\title{
Perinatal assessment of glycaemic control in newborn infants of diabetic mothers
}

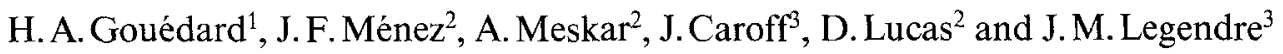 \\ Departments of ${ }^{1}$ Paediatrics and Neonatology, ${ }^{2}$ Biochemistry A and ${ }^{3}$ Nuclear Medicine, Hôpital Morvan, Brest, France
}

\begin{abstract}
Summary. The glycaemic control of infants and of their mothers was studied at delivery and on day 7 after birth in 11 control and 20 insulin-dependent diabetic women. At delivery, venous blood glucose was lower in infants of diabetic mothers compared with control infants $(p<0.02)$. Seven days after birth, no significant difference in blood glucose could be found between control and infants of diabetic mothers. Cpeptide levels were higher in infants of diabetic mothers compared with control infants $(p<0.01)$. On day 7 after birth, the C-peptide levels remained higher only in infants of Class B, C, $\mathrm{D}$ diabetic mothers. Glycosylated haemoglobin was lower in the venous blood of infants than of their mothers $(p<0.001)$.
\end{abstract}

Glycosylated haemoglobin was lower in control mothers than in diabetic mothers $(p<0.05)$, but it was higher in the venous blood samples from control infants compared with infants of diabetic mothers at delivery $(p<0.05)$ and 7 days after $(p<$ 0.01 ). At delivery infants' glycaemia and infants' glycosylated haemoglobin correlated $(r=0.44, p<0.02)$. C-Peptide and glycosylated haemoglobin levels in infants at delivery also correlated $(r=-0.42, p<0.05)$.

Key words: Blood glucose, C-peptide, glycosylated haemoglobin, pregnancy, newborn infants, diabetic mothers.
Fetal macrosomia in diabetic pregnancies has been attributed to hyperinsulinaemia [1-3], which occurs in response to fetal hyperglycaemia. However, few studies have reported the glycaemic control of the fetus during the prenatal period [4-8]. Hypoglycaemia in infants of diabetic mothers, often observed at delivery, is an insufficient guide to the assessment of hypoglycaemia in fetal life. The glycosylated haemoglobin (Gly-Hb) concentration tends to reflect glycaemic control during the previous weeks, and its determination after delivery may help in the assessment of glycaemic control in utero. Because of difficulties in measuring $\mathrm{Gly}-\mathrm{Hb}$ in neonatal blood using isoelectric focussing $[5,9,10]$ or cation exchange chromatography [11-14], the thiobarbituric acid (TBA) colorimetric chemical assay or affinity chromatography method $[15,16]$ are the most appropriate for such assessment. The TBA procedure directly measures ketoamine linkage. In addition, the C-peptide levels at delivery allow estimation of insulinaemia in the fetus.

The aim of the present study was to determine the glycaemic control of infants of diabetic mothers in the perinatal period. For this purpose, infant-mother paired samples from control and insulin-dependent diabetic pregnancies were studied.

\section{Subjects and methods}

\section{Subjects}

Infants and their mothers attended the Department of Paediatrics and Gynaecology, CHU Morvan, Brest, France. Three groups were studied: group 1:11 control mothers with no history of diabetes and with a normal oral glucose tolerance test according to the criteria of O'Sullivan and Mahan [18]; group 2:13 gestational diabetic patients with an abnormal glucose tolerance test (White's Class A), all were treated with insulin; group 3: seven Type 1 diabetic women (three White's Class B, two Class C and two Class D). All diabetic patients were treated with insulin. The number of births by normal vaginal delivery were respectively seven, ten and three and by Caesarean section four, three and four in the three groups. All mothers were given a slow regular glucose infusion at a rate of $4-5 \mathrm{~g} / \mathrm{h}$ for the $2-3 \mathrm{~h}$ before delivery. The mean gestational ages for the infants were respectively: group 1: $37.4 \pm 2.3$ weeks (range $35-40$ weeks), group 2: $38.4 \pm$ 1.4 weeks (range $36-40$ weeks) and group $3: 36.7 \pm 0.7$ weeks (range 36-38 weeks). Ultrasonography was used for assessment of gestational age, and the gestational ages were ascertained at delivery [19]. The mean infant birth weights were: group 1: $2.41 \pm 0.82 \mathrm{~kg}$ (range $1.90-3.42 \mathrm{~kg}$ ), group $2: 3.38 \pm 0.35 \mathrm{~kg}$ (range $2.40-3.90 \mathrm{~kg}$ ), group 3 : $3.39 \pm 0.38 \mathrm{~kg}$ (range $2.70-3.70 \mathrm{~kg}$ ). The control infants presented a heterogeneous population with various reasons for admission to hospital (infection, minor respiratory distress syndromes), but none had hypoglycaemia (plasma glucose $<1.65 \mathrm{mmol} / \mathrm{l}$ ) during the first $3 \mathrm{~h}$ of neonatal life.

No infant was fed by maternal milk during the 7 days after birth. Between days 0 and 3 , five infants in group 1 and three infants in 
group 2 were fed continuously with Alprem (Nestlé, Vevey, Switzerland) by gastric intubation, six and ten in the same groups by humanised milk (SMA, Wyeth-Byla, Paris, France). Between days 3 and 7 the infants were fed every $3 \mathrm{~h}$ with the same milk used between days 0 and 3. In group 3, every infant received humanised milk (SMA). Moreover, glucose was infused intravenously in two infants on days 0 and 1 , in the five other infants $2 \%$ lactose was added to the humanised milk. The oral diet with humanised milk and $2 \%$ lactose (4.5-6.5 g lactose/day) was given between days 3 and 7 in all the infants of this group.

\section{Methods}

All the determinations were carried out on venous blood. Gly-Hb was measured using a TBA semi-automated procedure [17] and blood glucose and C-peptide were analysed (see below).

Whole blood samples were collected in EDTA and immediately centrifuged (1400 $\mathrm{g}$ for $10 \mathrm{~min}$ ). Maternal samples were drawn within $6 \mathrm{~h}$ of delivery and infant samples were drawn within $3 \mathrm{~h}$ of delivery. Blood samples were collected before feeding at $08.00 \mathrm{~h}$ from the infants on day 7 of life. Plasma samples were analysed for glucose by a glucose oxidase technique using a glucose analyser (Beckman, Fullerton, California, USA) and for C-peptide by radioimmunoassay (mat $\mathrm{C}$ peptid, Mallinckrodt, Diedzenbach, FRG). The sensitivity of the $\mathrm{C}$ peptide assay was $10 \mathrm{pmol} / 1$. The coefficient of variation was $<10 \%$ and according to the supplier, cross-reaction with human proinsulin was $<10 \%$. Haemolysates for Gly-Hb assays were prepared within $12 \mathrm{~h}$ from saline ( $\mathrm{NaCl} 0.15 \mathrm{~mol} / \mathrm{l})$-solution-washed erythrocytes by osmotic lysis with water, shaking with carbon tetrachloride and subsequent centrifugation ( $2000 \mathrm{~g}$ for $10 \mathrm{~min}$ ) to remove cellular debris. The overnight dialyzed (against $\mathrm{NaCl}, 0.15 \mathrm{~mol} / \mathrm{l}$ ) haemolysates were adjusted to $100 \mathrm{~g} / 1$ and hydrolyzed by the technique of Pecoraro et al. [20]. After hydrolysis, the 5-hydroxymethylfurfural (5-HMF) was determined, using TBA colorimetric reaction by means of an auto-analyser II (Technicon, Domont, France) as described previously [17]. The method was standardized using a poll of frozen haemoglobin, distributed in $1 \mathrm{ml}$ aliquots and stored at $-20^{\circ} \mathrm{C}$. Results were expressed in nmol 5-HMF/mg haemoglobin. The between-assay precision for the standard was $4.8 \%$. All the determinations for glucose, Cpeptide and Gly-Hb were carried out in duplicate.

Statistical analysis included Student's unpaired t-test and linear regression analysis.

\section{Results}

There were no significant differences in gestational age between the study groups. The infants of diabetic mothers were heavier than control infants $(p<0.001)$. The results of blood glucose, C-peptide and Gly-Hb at delivery and on day 7 after birth for the three groups studied are summarised in Table 1 . At delivery the plasma glucose concentration was lower in infants of diabetic mothers compared with controls $(p<0.02)$, especially in infants of group 3 mothers (Class B-D; $p<0.001$ ), which suggests neonatal hypoglycaemia in infants of diabetic mothers. The differences between control infants and infants of group 2 mothers (Class A) were not significant. It was noteworthy that the differences between blood glucose concentrations at delivery and 7 days after were always significant $(p<0.05$ for infants of group 1 and 2 mothers, $p<0.001$ for infants of group 3 mothers), but the differences between the glycaemia on day 7 of life were not significant between any group. Therefore neonatal hypoglycaemia in infants of

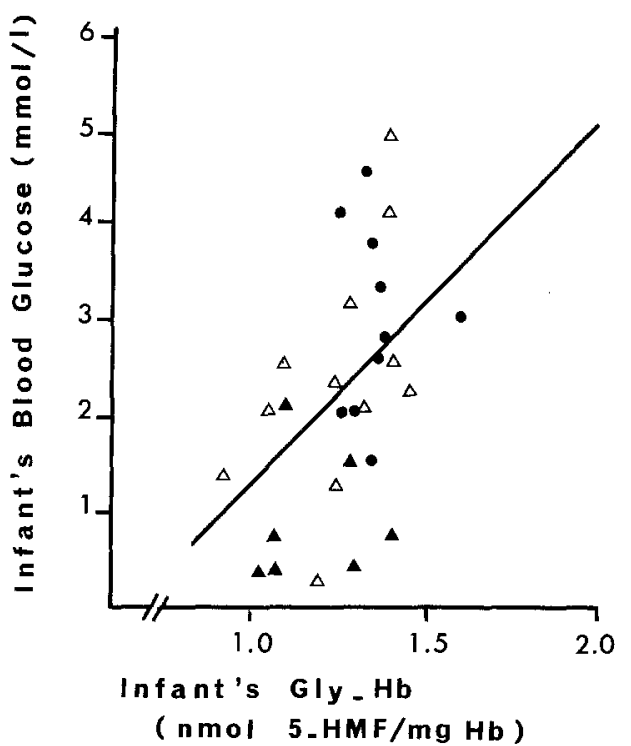

Fig. 1. Relationship between blood glucose and $\mathrm{Gly}-\mathrm{Hb}$ at delivery in 10 control infants $(-)$ and 19 infants of diabetic mothers: class $A(\Delta)$, classes B, C, D ( $\Delta$ ). Regression line $y=3.7 \times-2.4, r=0.44, p<0.02$

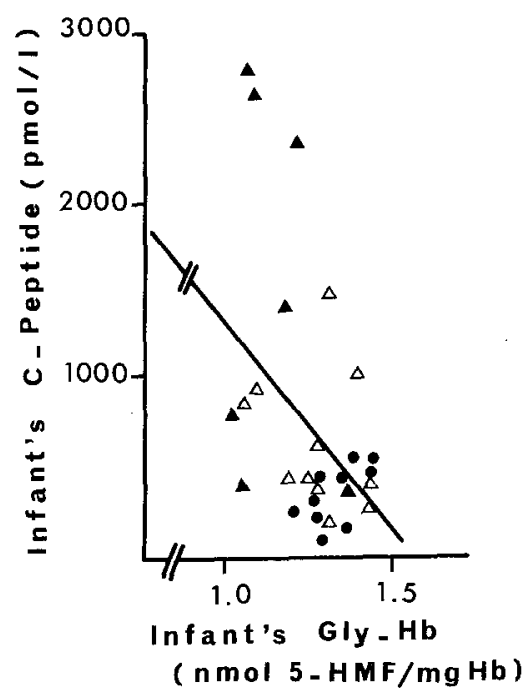

Fig. 2. Relationship between $\mathrm{C}$-peptide and Gly-Hb at delivery in 10 control infants $(-)$ and 18 infants of diabetic mothers: class $A(\Delta)$, classes B, C, D ( $\Delta$ ). Regression line $y=-2460 \times+3910, r=-0.42$, $p<0.05$

diabetic mothers is a transient condition which can be corrected easily. As expected, plasma glucose concentrations at delivery were higher in diabetic mothers than in control mothers $(p<0.001)$, especially in group 3 $(9.8 \pm 3.6$ versus $3.73 \pm 0.59 \mathrm{mmol} / 1, p<0.001)$. Serum glucose levels were significantly lower in infants at birth than in paired mothers for every group, in group $1(\mathrm{p}<$ $0.05)$; this difference was highly significant in group 3 $(\mathrm{p}<0.001)$.

At delivery, the mean C-peptide level of Class A diabetic mothers was not significantly lower than control mothers. The C-peptide levels were higher in the infants of diabetic mothers, especially in the infants of group 3 
Table 1. Values for blood glucose, C-peptide, and glycosylated haemoglobin in infants and their mothers at delivery and on day 7 after birth

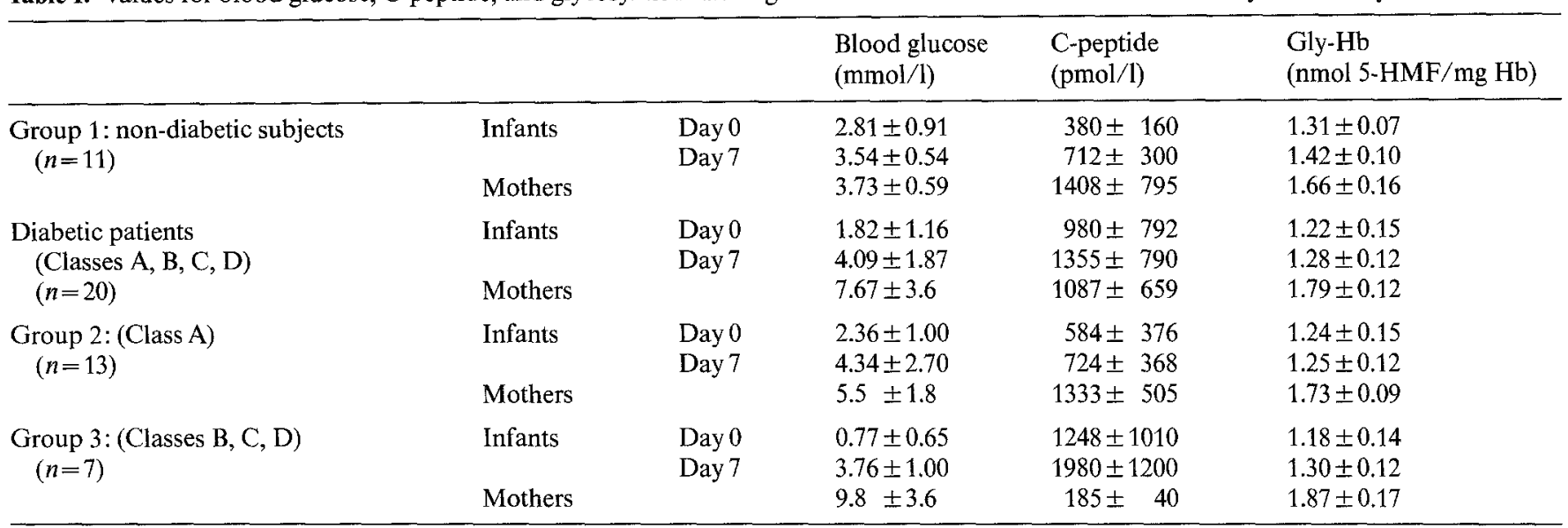

Results expressed as mean $\pm \mathrm{SD}$

$(1248 \pm 1010$ versus $380 \pm 160 \mathrm{pmol} / 1, p<0.05)$. In all groups, the $\mathrm{C}$-peptide levels increased between delivery and day 7 , so the differences remained significant between control infants and infants of group 3 mothers; in this group hyperinsulinaemia was persistent 7 days after delivery. In group 2 infants, the mean C-peptide level was slightly higher than controls at delivery, but 7 days after, the pancreatic secretion was the same for both.

More interesting were the results of Gly- $\mathrm{Hb}$. The Gly-Hb of diabetic mothers was higher than in controls ( $p<0.05$ between controls and group 3 mothers). No significant difference was found between the Gly-Hb of pregnant women and non-pregnant women $(1.66 \pm 0.16$ versus $1.62 \pm 0.11 \mathrm{nmol} 5-\mathrm{HMF} / \mathrm{mg} \mathrm{Hb}$ ). For infants in every group the $\mathrm{Gly}-\mathrm{Hb}$ was $20-40 \%$ lower than in control adults. The Gly-Hb concentrations were lower in infants of diabetic mothers compared to control infants $(p<0.05)$, especially in babies of group 3 mothers. In every group a slight increase was found between infants' Gly-Hb concentration on days 0 and 7 , but the Gly-Hb level remained lower in infants of diabetic mothers than in control infants $(p<0.01 ; 7$ days after birth). By regression analysis a correlation could be found between the infants' glycaemia and Gly-Hb at delivery ( $r=0.44, n=29, p<0.02$; Fig. 1 ) and between $\mathrm{C}$-peptide levels and Gly-Hb concentrations determined in infants at delivery $(r=-0.42, n=28, p<0.05$; Fig. 2). The decrease in the infants' glycaemia was associated with an increase of C-peptide levels at delivery, but a significant correlation between both parameters failed. The increase in birth weight was associated with an increase of C-peptide levels at delivery $(p<0.05)$, but no correlation could be found between maternal Gly$\mathrm{Hb}$ levels and the birth weights of their infants. A comparison of $\mathrm{Gly}-\mathrm{Hb}$ in infants and their mothers showed an increase in mother $\mathrm{Gly}-\mathrm{Hb}$ with a decrease in infant $\mathrm{Gly}-\mathrm{Hb}$ but a significant correlation between both parameters could not be found. In groups 2 and 3 the increase in mothers' glycaemia was associated with a decrease in infants' glycaemia, but the correlation was not significant.

\section{Discussion}

Hypoglycaemia and macrosomia are well recognised in infants of diabetic mothers. Macrosomia is demonstrated clearly in this study, as the gestational age of the infants was not significantly different. A variable incidence of hyperglycaemia or hypoglycaemia has been reported [2, 21-25]. In those studies, the increases of glycaemia in infants of diabetic mothers were never significant. Moreover the determinations were carried out on cord blood which does not reflect exactly the infants' metabolism as reported for other blood parameters $[26$, 27].

Accurate assessment of fetal hyperinsulinism by the levels of insulin in blood in infants of diabetic mothers is usually not feasible, because of interference in the insulin immunoassay by the transplacental passage of maternal antibodies generated by exogenous insulin therapy. Instead of insulin, measurement of C-peptide levels provides an accurate assessment of the secretion of endogenous fetal insulin, despite the presence of circulating antibodies. Serum C-peptide levels in the longterm diabetic patients were very low in contrast to their infants as previously reported [22]. Thus, insulin-treated mothers, who become diabetic during pregnancy, had $C$-peptide levels close to the control group of mothers. Class A diabetic mothers have insufficient $\beta$-cell activity which is supported by the increase of glycaemia at delivery ( $p<0.01$ versus control). They require exogenous insulin to reduce the increase in blood glucose. The increase of C-peptide levels in every group of infants between days 0 and 7 can be explained by the stimulation of insulin secretion induced by oral feeding. Therefore 
in infants of diabetic mothers the hyperinsulinism was not rapidly corrected even after 7 days of extra-uterine life. The addition of $2 \%$ lactose to the humanised milk in the feeding of those infants of diabetic mothers is insufficient by itself to explain the maintenance of the high insulin secretion in those infants. In spite of an obvious corrected glycaemia, the nutritional control of those infants beyond day 7 of life must be required to avoid a new decrease of blood glucose.

Measurement of glycosylated haemoglobin provides an integrated, retrospective index of glucose control, reflecting the mean blood glucose concentration over the previous weeks before its measurement. The determination of $\mathrm{Gly}-\mathrm{Hb}$ in neonatal blood is a difficult task using ion exchange or isoelectric focussing methods. But, colorimetric assay offers a convenient tool for measuring the amount of hexose chemically linked to proteins. The technique used here, and affinity chromatography used by other authors $[15,16]$, permits the assessment of fetal glycosylated haemoglobin. In every group the $\mathrm{Gly}-\mathrm{Hb}$ level was $22-37 \%$ lower in infants than in mothers, which is in agreement with differences reported using the affinity chromatography technique $[15,16]$. This can be explained in three ways: (1) by the lower blood glucose concentration in the fetus compared to its mother, (2) by the shorter half-life of fetal haemoglobin compared with adult haemoglobin [28], and (3) by the decrease in fetal erythrocyte membrane permeability to glucose [29]. The lower Gly-Hb values in the Class B, C and D infants might be due to the increase in erythropoiesis of such infants. However, the shorter half-life of the erythrocyte in infants of diabetic mothers was described and attributed to the fact that they are born before term [2]. In this study, as control infants have the same gestational age, the half-life of erythrocytes would be comparable. However the infants affected by the maternal diabetic process may have an abnormal haematopoiesis, such a study merits investigation.

There have been few studies [4-8, 15-16] of Gly-Hb in infants of diabetic mothers. Fitzgerald et al. [5], using isoelectric focussing, found that the level of Gly- $\mathrm{Hb}$ in infants of diabetic mothers could not be correlated to an increase of Gly-Hb in their mothers. Schwartz et al. [30], using isoelectric focussing and DEAE cellulose ion exchange chromatography, were not able to demonstrate any difference in acetylation or glycosylation occurring in the infants of control, gestational diabetic or Class B-D diabetic mothers. Caangay et al. [31], in a preliminary communication, using the TBA colorimetric method, found no difference between infants of control and diabetic mothers. For Zeller et al. [8], using the TBA colorimetric method, the Gly-Hb values of control infants were not significantly lower than infants of diabetic mothers, while a significant correlation was found between maternal and infants' Gly-Hb. Sosenko et al. [6] and Worth et al. [7] have reported a significant relationship between maternal and infant Gly-Hb. More- over, a correlation between serum C-peptide levels and TBA value in infants of diabetic mothers was found, but cord blood samples were used [6]. In our study, the significant lower Gly- $\mathrm{Hb}$ level in infants of diabetic mothers than in control infants, at delivery and 7 days after birth, associated with a significant correlation between glycaemia and Gly- $\mathrm{Hb}$, and between C-peptide levels and infants' Gly-Hb at delivery, may suggest normoglycaemia or hypoglycaemia during the later weeks of fetal life secondary to fetal hyperinsulinism. To confirm such a hypothesis the half-life of erythrocytes of infants of diabetic mothers should be elucidated further. Moreover, the determination of Gly-Hb using a high pressure liquid chromatography procedure [32], which has the main advantage of measuring 5-HMF without interference by background colour absorbance, should give more accurate information about 5-HMF released from fetal haemoglobin.

Acknowledgements. The authors thank Dr. J. Egan for valuable discussions and Mrs. O.Simon for typing the manuscript.

\section{References}

1. Ashworth HA, Leach FN, Milner RDS (1973) Development of insulin secretion in the human fetus. Arch Dis Child 48: 151-152

2. Pedersen J (1977) The pregnant diabetic and her newborn, 2nd edn. Munksgaard, Copenhagen

3. Susa JB, McCormic KL, Widness JA, Singer DB, Oh W, Adamsons K, Schwartz R (1979) Chronic hyperinsulinemia in the fetal Rhesus monkey. Effects on fetal growth and composition. Diabetes 28: 1058-1063

4. Fadel HE, Reynolds A, Stallings M, Abraham E (1981) Minor (glycosylated) hemoglobins in cord blood of infants of normal and diabetic mothers. Am J Obstet Gynecol 139: 397-402

5. Fitzgerald MD, Cauchi MN (1980) Determination of glycosylated hemoglobins in neonatal blood by isoelectric focusing. Am J Hematol 9:311-317

6. Sosenko JM, Kitzmiller JL, Fluckiger R, Loo SW, Younger DM, Gabbay KH (1982) Umbilical cord glycosylated hemoglobin in infants of diabetic mothers: relationships to neonatal hypoglycemia, macrosomia and cord serum C-peptide. Diabetes Care 5: 566-570

7. Worth R, Ashworth L, Home PD, Gerrard J, Lind T, Anderson J, Alberti KGMM (1983) Glycosylated haemoglobin in cord blood following normal and diabetic pregnancies. Diabetologia 25: $482-485$

8. Zeller WP, Susa JB, Widness JA, Schwartz HC, Schwartz R (1983) Glycosylation of hemoglobin in normal and diabetic mothers and their fetuses. Pediatr Res 17: 200-203

9. Mayer TK, Freedman ZR (1983) Protein glycosylation in diabetes mellitus: a review of laboratory measurements and of their clinical utility. Clin Chim Acta 127: 147-184

10. Poon P, Turner RC, Gillmer MDG (1981) Glycosylated fetal haemoglobin. Br Med J 283: 469

11. Abraham EC, Cope ND, Braziel NN, Huisman THJ (1979) On the chromatographic heterogeneity of human fetal hemoglobins. Biochim Biophys Acta 577: 159-169

12. Daneman D, Tsalikian E, Hengstenberg F, Becker DJ, Drash AL (1980) Glycosylated haemoglobin in children with insulindependant diabetes mellitus. Diabetologia 19: 423-426

13. Svendsen PA, Christiansen IS, Søegaard U, Welinder BS, Nerup I (1980) Rapid changes in chromatographically determined haemoglobin $\mathrm{A}_{1 \mathrm{c}}$ induced by short serum changes in glucose concentration. Diabetologia 19: 130-136 
14. Perier C, Hivert M, Frey J, Rousset H, Janin J (1980) Relationship between hemoglobin $\mathrm{A}_{1 \mathrm{c}}$ and insulin C-peptide in anomalies of carbohydrate metabolism. Biomedicine 33: 232-236

15. Talwar D, Barr B, Kesson CM, Robb DA (1983) Determination of glycosylated adult and fetal hemoglobins by affinity chromatography. Clin Chim Acta 128: 61-67

16. Hall PM, Cawdell GM, Cook JGH, Gould BJ (1983) Measurement of glycosylated haemoglobins and glycosylated plasma proteins in maternal and cord blood using an affinity chromatography method. Diabetologia 25: 477-481

17. Ménez JF, Meskar A, Lucas D, Darragon T, Floch HH, Bardou LG (1981) Glycosylated hemoglobin and serum proteins: semiautomated estimation. Clin Chem 27: 1947-1948

18. O'Sullivan JB, Mahan CM (1964) Criteria for the oral glucose tolerance test in pregnancy. Diabetes 13:278-285

19. Farr V, Mitchell RG, Meligan GA, Larjin JM (1966) Definition of some external characteristics in the assessment of gestational age in the newborn infant. Dev Med Child Neurol 8: 507-511

20. Pecoraro RE, Graf RJ, Halter JB, Beiter H, Porte D Jr (1979) Comparison of colorimetric assay for glycosylated hemoglobin with ion-exchange chromatography. Diabetes 28: $1120-1125$

21. Block MB, Pildes RS, Mossahboy NA, Steiner DF, Rubenstein AH (1974) C-peptide immunoreactivity: a new method for studying infants of insulin-treated diabetic mothers. Pediatrics 53: 923-928

22. Heding LG, Persson B, Stangenberg M (1980) $\beta$-cell function in newborn infants of diabetic mothers. Diabetologia 19: 427-432

23. Burke BJ, Owens CJ, Pennock CA (1981) Cord blood C-peptide: glucose ratio a good indicator of $\beta$-cell function in infants of diabetic mothers. Diabetologia 20: 511 (Letter)

24. Lin CC, River P, Moawad AH, Blix PM, Abraham M, Rubenstein $\mathrm{AH}$ (1981) Prenatal assessment of fetal outcome by amniotic fluid C-peptide levels in pregnant diabetic women. Am J Obstet Gynecol 141: 671-676
25. Ylinen K, Raiviok K, Teramo K (1981) $\mathrm{HbA}_{1 \mathrm{c}}$ predicts the perinatal outcome in insulin-dependant diabetic pregnancies. $\mathrm{Br} \mathbf{J}$ Obstet Gynecol 88: 961-967

26. Ginsburg BE, Zetterstrom R (1980) Serum cholesterol concentration in early infancy. Acta Pediatr Scand 69: 581-585

27. Gouedard H, Léglise D, L'Hostis D, Conan G (1982) Evolution des taux sériques du cholestérol et de ses fractions lipoprotéiniques en période néonatale. Arch Fr Pediatr 39: 437-440

28. Bratteby LE, Garby L (1960) Studies on erythrokinetics in infancy. III. The mean life span and the life span frequency function of red blood cells formed during fetal life. Acta Pediatr Scand 57: 311-320

29. Widdess NF (1960) Transport mechanisms in the fetus. Br Med Bull 17: 107-110

30. Schwartz HC, Widness J, Thompson D, Tsuboi KK, Oh W, Schwartz R (1980) Glycosylation and acetylation of hemoglobin in infants of normal and diabetic mothers. Biol Neonate 38:71-75

31. Caangay DL, Curran JS, Malone JI (1979) Cord glycohaemoglobin of infants of diabetic and non-diabetic mothers. Clin Res 27: 812 (Abstract)

32. Ménez JF, Berthou F, Meskar A, Picart D, Le Bras R, Bardou LG (1984) Glycosylated haemoglobin: high-performance liquid chromatographic determination of 5-hydroxymethylfurfural after haemoglobin hydrolysis. J Chromatogr 279:339-350

Received: 8 March 1984

and in revised form: 4 September 1984

Dr. HA Gouédard

Service de Pédiatrie et Néo-Natalogie

Centre Hospitalier

F-29237 Morlaix Cédex

France 